\title{
Investigating the Effects of Exogenous Factors on Growth, Photosynthetic Pigments and Bud Induction in Gracilaria corticata var. cylindrica under In vitro Conditions
}

\author{
A. Anuraj ${ }^{*}$, Ajit Arun Waman², Chandra Prakash ${ }^{3}$, S. Dam Roy ${ }^{4}$, \\ M. Viji ${ }^{1}$, Manoj Baidya ${ }^{1}$ and N.K. Chadha ${ }^{3}$ \\ ${ }^{1}$ Division of Fisheries Science, ${ }^{2}$ Division of Horticulture and Forestry, ICAR-Central Island \\ Agricultural Research Institute, Port Blair, India \\ ${ }^{3}$ Division of Aquaculture, ICAR-Central Institute of Fisheries Education, Mumbai, India \\ ${ }^{4}$ Director, ICAR-Central Island Agricultural Research Institute, Port Blair, India \\ *Corresponding author
}

\section{A B S T R A C T}

\begin{tabular}{|l|}
\hline K e y w o r d s \\
Rhodophyta, \\
Seaweed, Media, \\
PGR, Explants. \\
\hline Article Info \\
\hline Accepted: \\
28 August 2017 \\
Available Online: \\
10 September 2017
\end{tabular}

Effect of kind and concentration of culture media, and plant growth regulators on in vitro response was studied in an economically important seaweed species viz. Gracilaria corticata var. cylindrica. Filter sterilized autoclaved artificial seawater medium at $100 \%$ concentration $\left(\mathrm{A}_{2}\right)$ was found to be the most optimum for in vitro culture as the cultured explants showed superiority in terms of growth and photosynthetic pigment content, apart from inducing lateral bud formation. Incorporation of cytokinin alone or in combination with auxin (IAA) promoted growth of seaweed explants in $A_{2}$ media. $A_{2}$ medium supplemented with kinetin at different concentrations showed the highest total chlorophyll content $\left(\mathrm{K}_{2}\right)$, highest total carotenoid content $\left(\mathrm{K}_{3}\right)$ and better induction of lateral buds $\left(\mathrm{K}_{1}\right)$. Hence, considering the promising response of artificial seawater supplemented with cytokinins and auxin for in vitro culture of the species, the present investigation could serve as a base study for formulating future research programmes.

\section{Introduction}

In the ever expanding billion-dollar seaweed industry, production contribution is mostly from the organized culture sector, while wild harvests accounts for mere $5 \%$ of the global seaweed production (FAO, 2014). Species of Gracilaria are cultivated in many parts of the world (FA0, 2016) and forms an important natural source of phyco-colloid- agar. However, the conventionally used vegetative fragments from the same mother plants over generations have reported to decrease the agar yield and quality, apart from increasing their susceptibility to various diseases (Hurtado and Chenney, 2003). Micropropagation is an in vitro culture technique, wherein axenic explants from any part of the seaweed are used to develop clones in artificial media under controlled conditions. Utility of in vitro multiplication techniques has been emphasized for commercial scale seaweed culture (Bohra et al., 2017). Supply of good quality seed material through in vitro means could improve the yield significantly through improved growth and phyco-colloid recovery, 
when compared with conventional vegetative fragments (Kumar et al., 2004). This technique could be employed for large scale production of superior quality seed material with uniform characteristics for seaweed farming. Despite the fact that tissue culture aspects have been attempted in 85 species (Reddy et al., 2008), the repeatability of the developed protocol has not very been successful even in same species grown elsewhere.

Addition of exogenous hormones to culture media in controlled environments could enhance the culture establishment and subsequent development. Endogenous presence of plant growth regulators (PGRs) such asauxins and cytokinins have been reported in different seaweed species (Jacobs et al., 1985; Bradley, 1991; Jacobs, 1993; Stirk and van Staden, 1997; Stirk et al., 2003, 2004). Imelda et al., (1998) suggested that use of exogenous PGRs could act synergistically with the native hormones and promote the culture growth.

Positive responses with use of PGRs in some seaweed species have been reported by earlier researchers (Kaczyna and Megnet, 1993; Yokoya et al., 2004; Hayashi et al., 2008; Yong et al., 2014a). Report by AguirreLipperheide et al., (1995) also suggested that red seaweed species respond more to exogenously supplied PGRs than other seaweeds.

Addition of PGRs aids in regaining the morphology of seaweeds treated with antibiotics in laboratory to obtain axenic explants (Bradley and Chenney, 1991). The present study concerned a preliminary attempt to investigate the effects of culture media similar to the natural environment and PGRs on the micropropagation of Gracilaria corticata var. cylindrica in Andaman and Nicobar Islands, India.

\section{Materials and Methods}

Segments of seaweed species Gracilaria corticata var. cylindrica were collected during low tide from Burma Nallah region of South Andaman, Andaman and Nicobar Islands (India). Healthy segments $(2-5 \mathrm{~cm})$ were collected and cleaned off with sterilized cotton and tweezers to eliminate the epiphtyes followed by rinsing in filter sterilized $(0.45 \mu)$ seawater. Such explants were first treated with antibiotic mixture $\mathrm{A}_{3}$ (Liu and Kloareg, 1992) in autoclaved beaker for $5 \mathrm{~d}$. Subsequently, fragments were washed with filter sterilized autoclaved seawater and treated with $0.1 \%$ detergent (Charmy green) for 10 min (Kumar et al., 2007) and thereafter with betadine.

The explants were finally cut into $c a .1 \mathrm{~cm}$ size using sterile blades and such explants were used for successive experiments.

\section{Effect of media on seaweed cultures}

Following the surface sterilization procedure, effect of culture media on establishment of seaweed cultures were determined using two different media viz. filter sterilized autoclaved seawater (FSAS) and filter sterilized autoclaved artificial seawater (FSAAS) at three different concentrations (50\% (15 ppt), $100 \%$ (30 ppt) and 200\% (60 ppt)). The optimized concentration of media was used for the subsequent experiment.

\section{Effect of PGRs on seaweed cultures}

The effect of cytokinins (6Benzylaminopurine (B), Kinetin (K) and meta-topolin (M)) at different combinations with or without addition of auxin (indole-3acetic acid (I))was studied on culture response at three concentrations i.e. $2.5 \mathrm{mg} / \mathrm{L}\left(\mathrm{B}_{1}, \mathrm{M}_{1}\right.$, $\left.\mathrm{K}_{1}\right), 5 \mathrm{mg} / \mathrm{L}\left(\mathrm{B}_{2}, \mathrm{M}_{2}, \mathrm{~K}_{2}\right)$ and $7.5 \mathrm{mg} / \mathrm{L}\left(\mathrm{B}_{3}\right.$, $\mathrm{M}_{3}, \mathrm{~K}_{3}$ )in FSAAS at $100 \%$ concentration. In 
auxin supplemented treatments, a common dose of I $(0.2 \mathrm{mg} / \mathrm{L})$ was used. Both the experiments were conducted for $30 \mathrm{~d}$ and subculture was performed by changing the culture media after $15 \mathrm{~d}$. A photoperiod of 16:8 (L:D) was maintained throughout the culture period with $20 \mathrm{~W}$ fluorescent tubes (Phillips, India). Weight of the explants was recorded at fortnightly interval, whereas number of buds, chlorophyll content and carotenoid content were recorded before initiation and atthe end of the experiment. Chlorophyll and carotenoid contents were estimated following Wellburn (1994). Daily growth rate (DGR) was calculated following earlier reports (Loureiroet al., 2010). The statistical analysis of the data was done using Web Agri Statistical Package (WASP v. 2.0, Indian Council for Agricultural ResearchResearch Complex for Goa, Old Goa, India).

\section{Results and Discussion}

The results of the experiment showed that both kind and concentration of culture media had a profound influence on the growth of cultured explants ( $\mathrm{p}<0.05$, Table1-2). Natural seawater $\left(S_{2}\right)$ promoted maximum increase in weight of explants with highest DGR among the three different FSAS media tested. Culture of explants initiated in $\mathrm{A}_{2}$ established themselves with highest DGR and also gained maximum weight during subculture, while explants showed maximum weight during the first $15 \mathrm{~d}$ in $\mathrm{A}_{1}$ among the different FSAAS media (Table 1 and 2 ). The growth rate also gradually decreased with duration of culture. Both suboptimal and supraoptimal levels of media were not conducive for culture growth as bleaching of explants was observed in these concentrations of FSAAS media. Although Gracilaria has been reported to grow at low saline conditions (Bird and McLachlan, 1986), reduced growth (Graham and Wilcox, 2000; Jong et al., 2015) and bleaching (Jong et al., 2015) have been noticed. Loss of thallus rigidity has been reported at low salinity levels (Kumar et al., 2010). Salinity level has been reported to affect growth in red algae (Daugherty and Bird, 1988) and both low and high salinity levels inhibited culture growth in earlier reports (Cai, 2011). Decrease in growth rate with increase in salinity (Ding et al., 2013) was also evident in present experiment. This might be due to the damage to the outer protective covering of explants due to hyper saline conditions, which in turn hindered the culture growth. Negative growth rate was observed in media at high concentration which might be due to bleaching of explants. Ding et al., (2013) also observed negative growth at high salinity in Gracilaria species. In present experiment, the optimum salinity for growth of explants was observed to be 30 ppt in both the media $\left(S_{2} \& A_{2}\right)$, which is in line with the earlier reports (Bird and McLachlan, 1986; Ding et al., 2013; Jong et al., 2015). Further, $\mathrm{A}_{2}$ media at this salinity provided better environment for culture growth, which is in agreement with Kaladharan et al., (2003), who reported suitability of artificial seawater for in vitro culture of Gracilaria species.

Salinity of the culture media affected the photosynthetic pigments of the explants i.e. total chlorophylls and total carotenoids (Fig. 1). The concentration of chlorophylls decreased with salinity stress (low and high salinity media), when compared to the concentration prior to the treatments although carotenoid contents showed increase in all media under study except $A_{3}$. Irrespective of the culture medium, chlorophyll content reached maximum level at $30 \mathrm{ppt}$ and was found to be the highest in $\mathrm{A}_{2}$ media. These findings are supported by earlier reports in which photosynthetic rate was found to decrease in Gracilaria verrucosa in low salinity (Wang et al., 1993), while decrease of photosynthetic pigments was observed above and below 25-30 ppt in Hypnea cervicornis (Ding et al., 2013). 
Table.1 Effect of media on the seaweed explants (Culture initiation)

\begin{tabular}{|c|c|c|c|c|c|c|}
\hline Treatment & $\begin{array}{c}\text { Mean } \\
\text { Initial Weight }(\mathrm{g})\end{array}$ & $\begin{array}{l}\text { Mean Final } \\
\text { Weight (g) }\end{array}$ & $\begin{array}{c}\text { \%Weight } \\
\text { Change }\end{array}$ & Paired t test & $\begin{array}{c}\text { DGR } \\
\text { (Daily growth rate) }\end{array}$ & Remarks \\
\hline $\mathrm{S}_{1}(50 \% \mathrm{FSAS}$ media $)$ & $0.14 \pm 0.06$ & $0.15 \pm 0.04$ & +12.54 & NS & +0.06 & \\
\hline $\mathrm{S}_{2}(100 \% \mathrm{FSAS}$ media $)$ & $0.13 \pm 0.02$ & $0.19 \pm 0.02$ & +42.16 & $*$ & +2.81 & \\
\hline $\mathrm{S}_{3}(200 \% \mathrm{FSAS}$ media $)$ & $0.12 \pm 0.04$ & $0.12 \pm 0.04$ & +0.93 & NS & +1.32 & $* *$ \\
\hline $\mathrm{A}_{1}(50 \% \mathrm{FSAS}$ media $)$ & $0.11 \pm 0.04$ & $0.16 \pm 0.03$ & +47.04 & $*$ & +0.84 & \\
\hline $\mathrm{A}_{2}(100 \% \mathrm{FSAS}$ media $)$ & $0.14 \pm 0.03$ & $0.17 \pm 0.04$ & +19.81 & $*$ & +3.14 & \\
\hline $\mathrm{A}_{3}(200 \% \mathrm{FSAS}$ media $)$ & $0.15 \pm 0.02$ & $0.16 \pm 0.02$ & +2.17 & NS & +0.14 & $* *$ \\
\hline
\end{tabular}

Data are presented as means \pm standard error (S.E.)., ${ }^{*}$ - Significant; NS- Not significant; ** - Bleaching observed

Table.2 Effect of media on the seaweed explants (Sub culture)

\begin{tabular}{|c|c|c|c|c|c|c|}
\hline Treatment & $\begin{array}{c}\text { Mean } \\
\text { Initial Weight }(\mathrm{g})\end{array}$ & $\begin{array}{l}\text { Mean Final } \\
\text { Weight (g) }\end{array}$ & $\begin{array}{l}\text { \%Weight } \\
\text { Change }\end{array}$ & Paired $t$ test & $\begin{array}{c}\text { DGR } \\
\text { (Daily growth rate) }\end{array}$ & Remarks \\
\hline $\mathrm{S}_{1}(50 \%$ FSAS media $)$ & $0.15 \pm 0.04$ & $0.20 \pm 0.02$ & +9.48 & NS & +0.63 & \\
\hline $\mathrm{S}_{2}(100 \%$ FSAS media $)$ & $0.19 \pm 0.02$ & $0.16 \pm 0.04$ & +9.95 & $*$ & +0.66 & \\
\hline $\mathrm{S}_{3}(200 \%$ FSAS media $)$ & $0.12 \pm 0.04$ & $0.12 \pm 0.04$ & -4.88 & NS & -0.33 & $* *$ \\
\hline $\mathrm{A}_{1}(50 \%$ FSAS media $)$ & $0.16 \pm 0.03$ & $0.13 \pm 0.03$ & -14.31 & NS & -0.95 & $* *$ \\
\hline $\mathrm{A}_{2}(100 \%$ FSAS media $)$ & $0.17 \pm 0.04$ & $0.19 \pm 0.04$ & +13.54 & $*$ & +0.90 & \\
\hline $\mathrm{A}_{3}(200 \%$ FSAS media $)$ & $0.16 \pm 0.02$ & $0.13 \pm 0.03$ & -16.87 & $*$ & -1.12 & $* *$ \\
\hline
\end{tabular}

Data are presented as means \pm standard error (S.E.); *- Significant; NS- Not significant; ** - Bleaching observed 
Int.J.Curr.Microbiol.App.Sci (2017) 6(9): 3235-3246

Table.3 Effect of PGRs on the proliferation of explants (Culture initiation)

\begin{tabular}{lccccc}
\hline Treatment & $\begin{array}{c}\text { Mean } \\
\text { InitialWeight }(\mathrm{g})\end{array}$ & $\begin{array}{c}\text { Mean } \\
\text { Final Weight }(\mathrm{g})\end{array}$ & $\begin{array}{c}\text { \%Weight } \\
\text { Change }\end{array}$ & Paired t test & $\begin{array}{c}\text { Daily Growth Rate } \\
\text { (DGR) }\end{array}$ \\
\hline $\mathrm{A}_{2}$ & $0.14 \pm 0.005$ & $0.17 \pm 0.015$ & +26.21 & $*$ & +1.75 \\
$\mathrm{~B}_{1}$ & $0.09 \pm 0.016$ & $0.17 \pm 0.015$ & +35.54 & $*$ & +2.37 \\
$\mathrm{~B}_{1} \mathrm{I}$ & $0.08 \pm 0.029$ & $0.12 \pm 0.028$ & +39.85 & $*$ & +2.66 \\
$\mathrm{~B}_{2}$ & $0.08 \pm 0.056$ & $0.11 \pm 0.038$ & +33.71 & $*$ & +2.25 \\
$\mathrm{~B}_{2} \mathrm{I}$ & $0.11 \pm 0.035$ & $0.12 \pm 0.072$ & +38.75 & $*$ & +2.58 \\
$\mathrm{~B}_{3}$ & $0.12 \pm 0.055$ & $0.15 \pm 0.04$ & +20.67 & $*$ & +1.38 \\
$\mathrm{~B}_{3} \mathrm{I}$ & $0.12 \pm 0.05$ & $0.14 \pm 0.066$ & +23.93 & $*$ & +1.80 \\
$\mathrm{M}_{1}$ & $0.08 \pm 0.014$ & $0.14 \pm 0.06$ & +27.07 & $*$ & +2.68 \\
$\mathrm{M}_{1} \mathrm{I}$ & $0.11 \pm 0.037$ & $0.11 \pm 0.018$ & +40.15 & $*$ & +2.07 \\
$\mathrm{M}_{2}$ & $0.10 \pm 0.011$ & $0.14 \pm 0.045$ & +31.04 & $*$ & +1.11 \\
$\mathrm{M}_{2} \mathrm{I}$ & $0.12 \pm 0.031$ & $0.13 \pm 0.021$ & +31.59 & $*$ & +2.62 \\
$\mathrm{M}_{3}$ & $0.12 \pm 0.034$ & $0.15 \pm 0.037$ & +23.17 & $*$ & +2.18 \\
$\mathrm{M}_{3} \mathrm{I}$ & $0.10 \pm 0.025$ & $0.16 \pm 0.034$ & +39.28 & $*$ & +2.08 \\
$\mathrm{~K}_{1}$ & $0.09 \pm 0.035$ & $0.13 \pm 0.017$ & +32.75 & $*$ & +3.18 \\
$\mathrm{~K}_{1} \mathrm{I}$ & $0.09 \pm 0.013$ & $0.13 \pm 0.058$ & +31.13 & $*$ & +2.95 \\
$\mathrm{~K}_{2}$ & $0.05 \pm 0.036$ & $0.12 \pm 0.019$ & +47.75 & $*$ & +3.06 \\
$\mathrm{~K}_{2} \mathrm{I}$ & $0.09 \pm 0.016$ & $0.10 \pm 0.033$ & +44.19 & $* 19$ \\
$\mathrm{~K}_{3}$ & $0.12 \pm 0.018$ & $0.13 \pm 0.022$ & +45.90 & $*$ & +3.11 \\
$\mathrm{~K}_{3} \mathrm{I}$ & $0.09 \pm 0.03$ & $0.18 \pm 0.041$ & +46.64 & $*$ & $*$ \\
\hline
\end{tabular}

Data are presented as means \pm standard error (S.E.); *-Significant

$\mathrm{A}_{2}$ (control) - $100 \%$ FSAAS media; $\mathrm{B}_{1}, \mathrm{~B}_{2} \& \mathrm{~B}_{3}$ and $\mathrm{B}_{1} \mathrm{I}, \mathrm{B}_{2} \mathrm{I} \& \mathrm{~B}_{3} \mathrm{I}-\mathrm{A}_{2}$ media supplemented with 6Benzylaminopurine and $A_{2}$ media supplemented with 6-Benzylaminopurine and IAA; $M_{1}, M_{2} \& M_{3}$ and $M_{1} I, M_{2} I$ \& $\mathrm{M}_{3} \mathrm{I}-\mathrm{A}_{2}$ media supplemented with with meta-topolin and $\mathrm{A}_{2}$ media supplemented with meta-topolin and IAA; $\mathrm{K}_{1}$, $\mathrm{K}_{2} \& \mathrm{~K}_{3}$ and $\mathrm{K}_{1} \mathrm{I}, \mathrm{K}_{2} \mathrm{I} \& \mathrm{~K}_{3} \mathrm{I}-\mathrm{A}_{2}$ media supplemented with Kinetin and $\mathrm{A}_{2}$ media supplemented with Kinetin and IAA.

Table.4 Effect of PGR's on the proliferation of explants (Subculture)

\begin{tabular}{cccccc}
\hline Treatment & $\begin{array}{c}\text { Mean Initial Weight } \\
(\mathrm{g})\end{array}$ & $\begin{array}{c}\text { Mean Final Weight } \\
(\mathrm{g})\end{array}$ & \%Weight Change & Paired t test & $\begin{array}{c}\text { Daily Growth Rate } \\
(\text { DGR })\end{array}$ \\
\hline A2 & $0.17 \pm 0.015$ & $0.19 \pm 0.023$ & +12.75 & $*$ & +0.85 \\
B1 & $0.12 \pm 0.028$ & $0.13 \pm 0.034$ & +7.70 & NS & +0.51 \\
B1I & $0.11 \pm 0.038$ & $0.12 \pm 0.044$ & +7.48 & NS & +0.50 \\
B2 & $0.12 \pm 0.072$ & $0.07 \pm 0.053$ & +4.56 & $*$ & +0.30 \\
B2I & $0.15 \pm 0.04$ & $0.15 \pm 0.038$ & -37.63 & NS & -2.51 \\
B3 & $0.14 \pm 0.066$ & $0.16 \pm 0.085$ & -5.99 & NS & +0.40 \\
B3I & $0.14 \pm 0.06$ & $0.14 \pm 0.067$ & +7.40 & $*$ & +0.84 \\
M1 & $0.11 \pm 0.018$ & $0.12 \pm 0.015$ & +12.55 & $*$ & +0.91 \\
M1I & $0.14 \pm 0.045$ & $0.16 \pm 0.048$ & +13.59 & $*$ & +0.40 \\
M2 & $0.13 \pm 0.021$ & $0.14 \pm 0.019$ & +5.94 & $*$ & +0.50 \\
M2I & $0.15 \pm 0.037$ & $0.16 \pm 0.036$ & +7.54 & $*$ & +0.44 \\
M3 & $0.16 \pm 0.034$ & $0.17 \pm 0.042$ & +6.67 & $*$ & +0.63 \\
M3I & $0.13 \pm 0.017$ & $0.13 \pm 0.019$ & +16.23 & $*$ & +1.08 \\
K1 & $0.13 \pm 0.058$ & $0.14 \pm 0.062$ & +15.05 & $*$ & +1.00 \\
K1I & $0.12 \pm 0.019$ & $0.14 \pm 0.026$ & +11.03 & $*$ & +0.74 \\
K2 & $0.10 \pm 0.033$ & $0.11 \pm 0.035$ & +12.16 & $*$ & +0.81 \\
K2I & $0.13 \pm 0.022$ & $0.14 \pm 0.029$ & +11.76 & $*$ & +0.78 \\
K3 & $0.18 \pm 0.041$ & $0.20 \pm 0.042$ & +8.43 & $*$ & +0.56 \\
K3I & $0.13 \pm 0.052$ & $0.14 \pm 0.051$ & & $*$ & \\
\hline
\end{tabular}

Data are presented as means \pm standard error (S.E.); * Significant

$\mathrm{A}_{2}$ (control) - $100 \%$ FSAAS media; $\mathrm{B}_{1}, \mathrm{~B}_{2} \& \mathrm{~B}_{3}$ and $\mathrm{B}_{1} \mathrm{I}, \mathrm{B}_{2} \mathrm{I} \& \mathrm{~B}_{3} \mathrm{I}-\mathrm{A}_{2}$ media supplemented with 6Benzylaminopurine and $A_{2}$ media supplemented with 6-Benzylaminopurine and IAA; $M_{1}, M_{2} \& M_{3}$ and $M_{1} I, M_{2} I$ \& $\mathrm{M}_{3} \mathrm{I}-\mathrm{A}_{2}$ media supplemented with with meta-topolin and $\mathrm{A}_{2}$ media supplemented with meta-topolin and IAA; $\mathrm{K}_{1}$, $\mathrm{K}_{2} \& \mathrm{~K}_{3}$ and $\mathrm{K}_{1} \mathrm{I}, \mathrm{K}_{2} \mathrm{I} \& \mathrm{~K}_{3} \mathrm{I}-\mathrm{A}_{2}$ media supplemented with Kinetin and $\mathrm{A}_{2}$ media supplemented with Kinetin and IAA. 
Fig.1 Media effect on photosynthetic pigments and lateral bud development

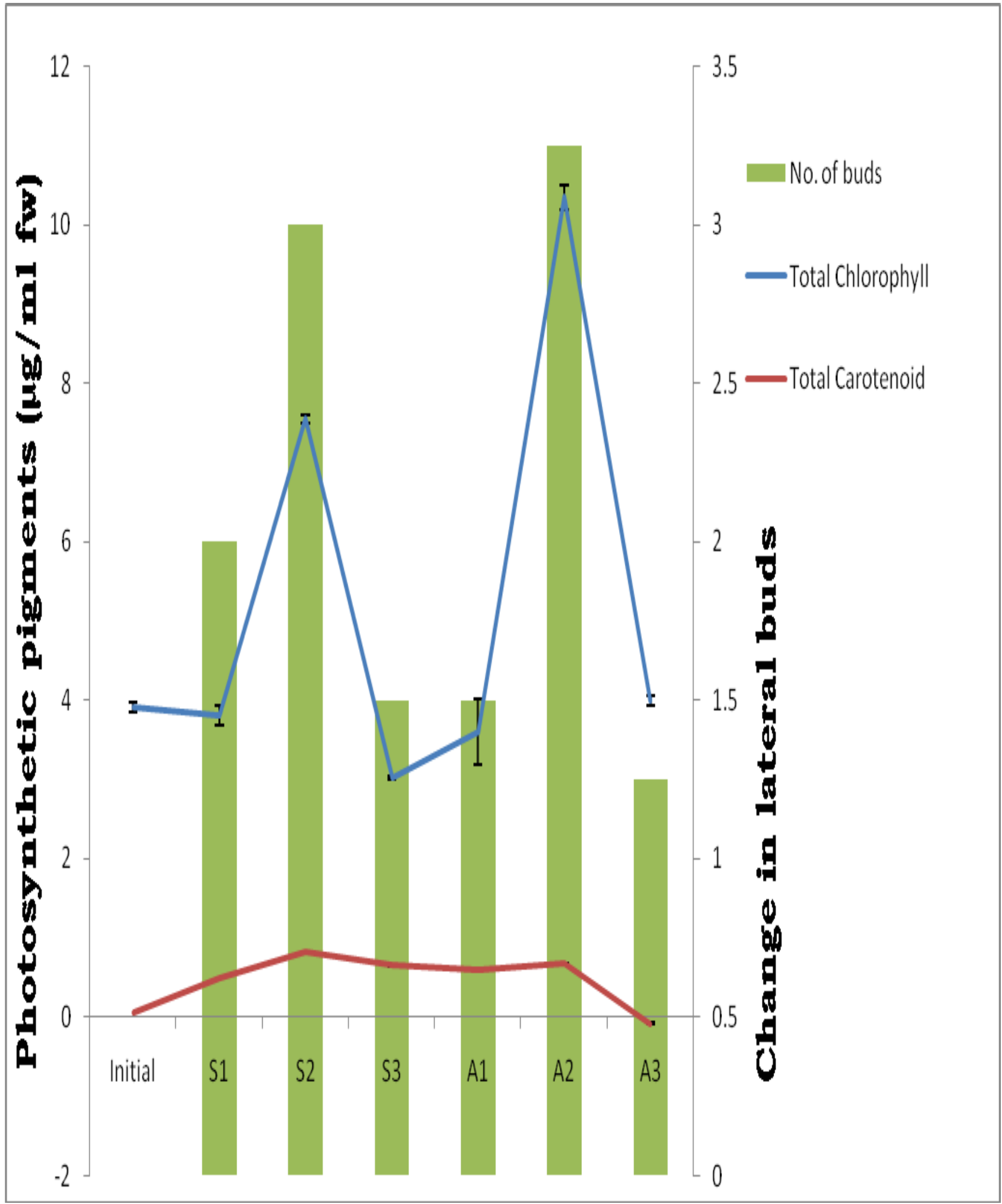

Data are presented as means \pm standard error (S.E.); $\mathrm{S}_{1}, \mathrm{~S}_{2}$ and $\mathrm{S}_{3}-50 \%, 100 \%$ and $200 \%$ FSAS media respectively $\mathrm{A}_{1}, \mathrm{~A}_{2}$ and $\mathrm{A}_{3}-50 \%, 100 \%$ and $200 \%$ FSAAS media respectively 
Fig.2 PGR's effect on photosynthetic pigments and lateral bud development

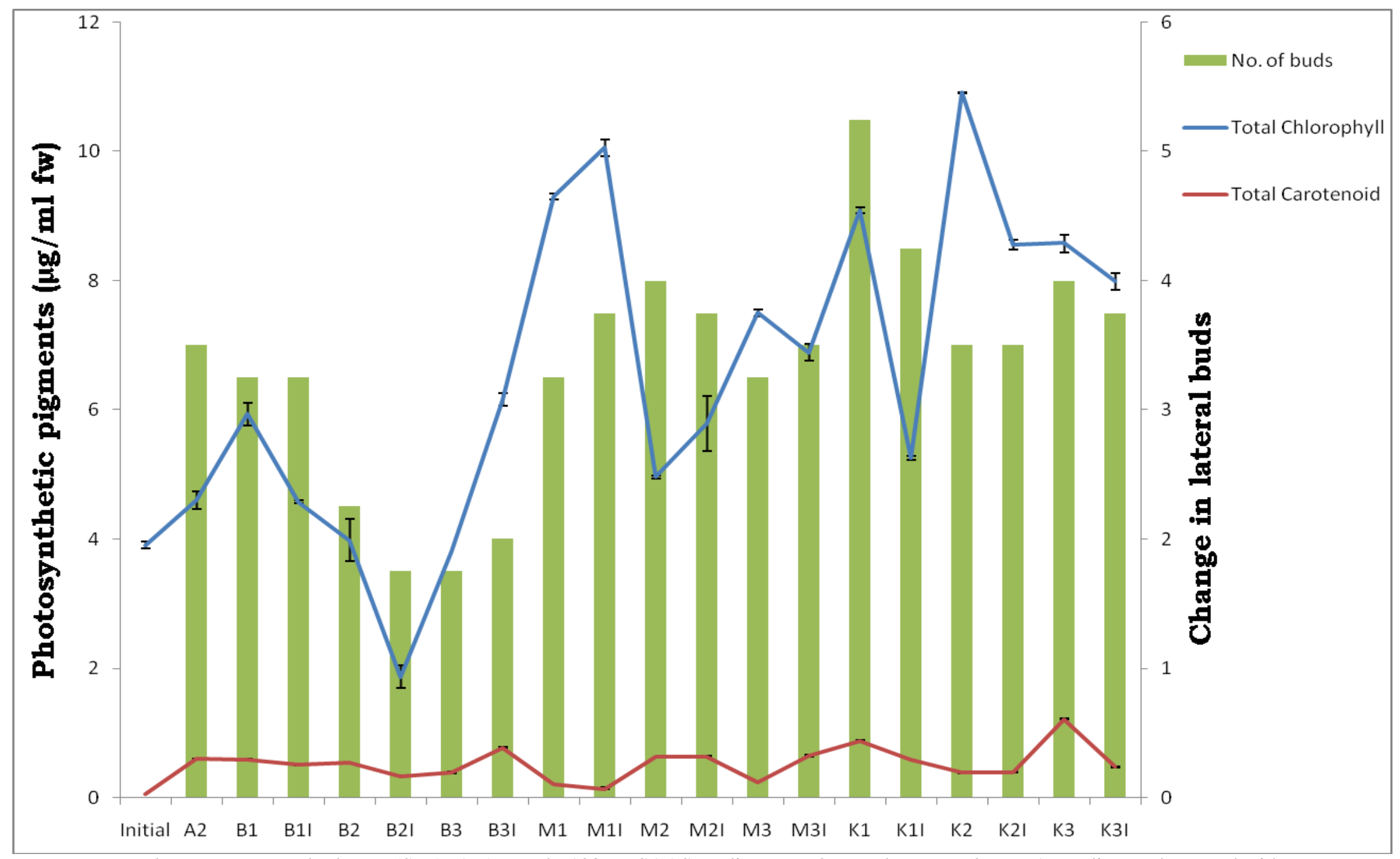

Data are presented as means \pm standard error (S.E.); $\mathrm{A}_{2}$ (control)- $100 \%$ FSAAS media; $\mathrm{B}_{1}, \mathrm{~B}_{2} \& \mathrm{~B}_{3}$ and $\mathrm{B}_{1} \mathrm{I}, \mathrm{B}_{2} \mathrm{I} \& \mathrm{~B}_{3} \mathrm{I}-\mathrm{A}_{2}$ media supplemented with 6-

Benzylaminopurine and $A_{2}$ media supplemented with 6-Benzylaminopurine and IAA; $\mathrm{M}_{1}, \mathrm{M}_{2} \& \mathrm{M}_{3}$ and $\mathrm{M}_{1} \mathrm{I}, \mathrm{M}_{2} \mathrm{I} \& \mathrm{M}_{3} \mathrm{I}-\mathrm{A}_{2}$ media supplemented with with metatopolin and $A_{2}$ media supplemented with meta-topolin and IAA; $K_{1}, K_{2} \& K_{3}$ andK $\mathrm{K}_{1}, \mathrm{~K}_{2} \mathrm{I} \& \mathrm{~K}_{3} \mathrm{I}-\mathrm{A}_{2}$ media supplemented with Kinetin and $\mathrm{A}_{2}$ media supplemented with Kinetin and IAA. 
Salinity stress also reduced the lateral buds formation, when compared to the normal salinity media $\left(S_{2}\right.$ and $\left.A_{2}\right)$. Lateral bud formation was more at lower salinities when compared with higher salinities in both the media (FSAS and FSAAS). Use of artificial media $\left(\mathrm{A}_{2}\right)$ promoted more lateral bud formation, when compared with the natural $\left(\mathrm{S}_{2}\right)$ media.

All the PGRs, either alone or in combination with IAA, promoted the growth of seaweed explants in $\mathrm{A}_{2}$ media except $\mathrm{B}_{3}, \mathrm{~B}_{3} \mathrm{I}$ and $\mathrm{M}_{3}$ during the initial period and positive effect was shown throughout the entire period in the media supplemented with $\mathrm{M}_{1} \mathrm{I}, \mathrm{K}_{1}$ and $\mathrm{K}_{1} \mathrm{I}$ $(\mathrm{p}<0.05)$ (Table 3,4). Positive response with the addition of phytoregulators has been reported earlier (Hayashi et al., 2008; Yong et al., 2014a). Phtyoregulators, auxins and cytokinins affect growth in red seaweeds (Jennings, 1971; Fries, 1974; Fries and Iwasaki, 1976). All the PGRs used in the experiment showed effect at their lowest concentration suggesting that continuous stimulatory effect are possible at this concentration. $\mathrm{M}_{1}$ in combination with IAA showed stimulatory effect for longer period. Combinations of PGRs enhanced growth in axenic cultures (Fries and Aberg, 1978, Bradley, 1990). Growth promotion of Kinetin on seaweed has been documented (Yokoya et al., 2004). The results of the experiment showed Kinetin at $2.5 \mathrm{mg} / \mathrm{L}$ when added to artificial seawater media promote growth of explants under in vitro condition. Among the different combinations of PGRs used in $\mathrm{A}_{2}$ media, both total chlorophyll and total carotenoid pigments of explants increased only with the addition of phytoregulators such as $\mathrm{B}_{3} \mathrm{I}, \mathrm{M}_{2}, \mathrm{M}_{2} \mathrm{I}, \mathrm{M}_{3} \mathrm{I}, \mathrm{K}_{1}$ and $\mathrm{K}_{3}$ when compared with either initial content or control $\mathrm{A}_{2}$ (Fig.2). The total chlorophyll pigment was found to be highest with the addition of $\mathrm{K}_{2}$ while total carotenoid was highest in media supplemented with $\mathrm{K}_{3}$. In relation to formation of lateral buds, $\mathrm{A}_{2}$ media supplemented with $K_{1}$ regenerated the highest no of buds. Our results were not corresponding to the results of Yokoya (2000) and Hayashi et al., (2007), where direct regeneration was promoted by combinations of IAA and BAP. These effects may be due to the difference in the media or species of seaweed used in the study coupled with the combination of various PGRs synergizing with endogenous hormones in a different way.

The present study illustrated that axenic explants could be maintained in artificial seawater media for in vitro culture. The preliminary results also suggestuse of kinetin as a potential PGR for growth and regeneration in in vitro culture of Gracilaria corticata var. cylindrica. The combination of auxin and cytokinin was also found promising. Further studies need to be focused on the mechanism of action of PGRs for understanding their role in culture proliferation in seaweed species.

\section{Acknowledgements}

Authors are thankful to the Indian Council of Agricultural Research, New Delhi for providing financial assistance for carrying out this work. First author also acknowledge helpful suggestions and research facilities provided by Dr. Pooja Bohra, Scientist, Division of Horticulture and Forestry, ICARCIARI, Port Blair.

\section{References}

Aguirre-Lipperheide, M., Estrada-Rodriguez, F. J., and Evans, L. V. 1995. Facts, problems and needs in seaweed tissue culture: an appraisal. Journal of Phycology. 31:677-688.

Bird, C.J., and McLachlan, J. 1986. The effect of salinity on distribution of species Gracilaria Grev. (Rhodophyta: 
Gigartinales): an experimental assessment. Botanica Marina. 29:231238.

Bohra, P., Waman, A.A., and Anuraj, A. 2017. Biotechnology as a tool for conservation and sustainable utilization of plant and seaweed genetic resources of tropical bay Islands, India In: Biotechnology for Sustainability: Achievements, Challenges and Prospectives (Eds). SubashBhore, K Marimuthu and M Ravichandran. AIMST University, Malaysia. Pp. 295304.

Bradley, P.M., 1991. Plant hormones do have a role in controlling growth and development of algae. Journal of phycology, 27(3): 317-321.

Bradley, P.M., and Cheney, D. P. 1990. Some effects of plant growth regulators on tissue cultures of the red alga Agardhiella subulata (Gigartinales, Rhodophyta). Hydrobiologia. 204/205:353-360.

Bradley, P.M., and Cheney, D. P. 1991. Beneficial applications of plant growthregulators to economically important seaweeds. Proceedings of the plant growth regulator society of America. 18:72-77.

Cai, X. L., 2011. Physiological response of Gracilaria lemaneiformis to temperature and salinity stress. Dissertation. Ningbo University. China.

Daugherty, B.K., and Bird, K.T. 1988. Salinity and temperature effects on agar production from Gracilaria verrucosa strain G-16. Aquaculture. 75(1-2): 105113.

Ding, L., Ma, Y., Huang, B., and Chen, S. 2013. Effects of seawater salinity and temperature on growth and pigment contents in Hypnea cervicornis J. Agardh

(Gigartinales, Rhodophyta). BioMed research
FAO (Food and Agriculture Organisation of the United Nations). 2014. The state of world fisheries and aquaculture. Food and Agriculture Organisation of the United Nations, Rome.

FAO (Food and Agriculture Organisation of the United Nations). 2016. The state of world fisheries and aquaculture. Food and Agriculture Organisation of the United Nations, Rome.

Fries, L., 1974. Growth stimulation of axenic red algae by simple phenolic compounds.Journal of Experimental Marine Biology and Ecology. 15: 1-9.

Fries, L., and Āberg, S. 1978. Morphogenetic effects of phenylacetic and p-OHphenylacetic acid on the green alga Enteromorpha compressa (L.) Grev. In axenic culture. Zeitschriftfür Pflanzenphysiologie, 88(5): 383-388.

Fries, L., and Iwasaki, H. 1976. PHydroxyphenylacetic acid and other phenolic compounds as growth stimulators of the red alga Porphyra tenera. Plant Science Letters, 6(5): 299307.

Graham, L.K., and Wilcox, L.W. 2000. The origin of alternation of generations in land plants: a focus on matrotrophy and hexose transport. Philosophical Transactions of the Royal Society of London B: Biological Sciences, 355(1398): 757-767.

Hayashi, L., de Paula, E.J. and Chow, F. 2007. Growth rate and carrageenan analyses in four strains of Kappaphycus alvarezii (Rhodophyta, Gigartinales) farmed in the subtropical waters of São Paulo State, Brazil. Journal of Applied Phycology. 19(5): 393-399.

Hayashi, L., Yokoya, N.S., Kikuchi, D.M., andOliveira, E.C. 2008. Callus induction and micropropagation improved by colchicines and phytoregulatorsin Kappaphycus alvarezii (Rhodophyta, Solieriaceae). 
Journal of Applied Phycology. 20: 653659.

Hurtado, A. Q., and Cheney, D. P. 2003. Propagule production of Eucheuma denticulatum (Burman) Collins ET Harvey by tissue culture. Botanica Marina. 46(4): 338-341.

Imelda, J., and Chennubhotla, V. S. K. 1998. Gibberellic acid and 2, 4-D as growth regulators in laboratory culture of seaweeds. Indian Journal of Marine Sciences. 28: 66-69

Jacobs, W.P., 1993. A search for some anglosperm hormones and their metabolites in Caulerpa paspaloides (chlorophyta). Journal of phycology. 29(5): 595-600.

Jacobs, W.P., Falkenstein, K. and Hamilton, R.H. 1985. Nature and amount of auxin in algae IAA from extracts of Caulerpa paspaloides (Siphonales). Plant physiology. 78(4): 844-848.

Jennings, R. C., 1971. Studies on the regulation of algal growth by gibberellin. Austrlian Journal of Bioliogical Sciences. 24: 1115-1124.

Jong, L.W., Thien, V. Y., Yong, Y. S., Rodrigues, K. F. and Yong, W.T. 2015 Micropropagation and protein profile analysis by SDS-PAGE of Gracilaria changii (Rhodophyta, Solieriaceae). Aquaculture Reports. 1: 10-4.

Kaczyna, F., and Megnet, R. 1993. The effects of glycerol and plant growthregulators on Gracilaria verrucosa (Gigartinales, Rhodophyceae). Hydrobiologia 268:5764.

Kaladharan, P., 2000. Artificial seawater for seaweed culture. Indian Journal of Fisheries. 47(3): 257-259.

Kumar, G.R., Reddy, C.R.K. and Jha, B. 2007. Callus induction and thallus regeneration from callus of phycocolloid yielding seaweeds from the Indian coast. Journal of Applied
Phycology. 19(1):15-25.

Kumar, G.R., Reddy, C.R.K., Ganesan, M., Thiruppathi, S., Dipakkore, S., Eswaran, K., SubbaRao, P.V. and Jha, B. 2004. Tissue culture and regeneration of thallus from callus of Gelidiella acerosa (Gelidiaies, Rhodophyta). Phycologia. 43(5): 596602.

Kumar, M., Kumari, P., Gupta, V., Reddy, C.R.K. and Jha, B. 2010. Biochemical responses of red alga Gracilariacorticata (Gracilariales, Rhodophyta) to salinity induced oxidative stress. Journal of Experimental Marine Biology and Ecology, 391(1): 27-34.

Liu, X. W., and Kloareg, B. 1992. Explant axenisation in for tissue culture in marine macro algae. Chinese Journal of Oceanology and Limnology. 10(3): 268-277.

Loureiro, R.R., Reis, R.P. andCritchley, A. T. (2010) In vitro cultivation of three Kappaphycus alvarezii (Rhodophyta, Areschougiaceae) variants (green, red and brown) exposed to a commercial extract of the brown alga Ascophyllum nodosum (Fucaceae, Ochrophyta). Journal of Applied Phycology. 22:101104.

Reddy, C.R.K., Jha, B., Fujita, Y. and Ohno, M. 2008. Seaweed micropropagation techniques and their potentials: an overview. Journal of Applied Phycology. 20(5): 609-617.

Stirk, W.A., and Staden,J. 1997. Isolation and identification of cytokinins in acommercial seaweed product made from Fucus serratus L. Journal of Applied Phycology. 9: 327-330.

Stirk, W.A., Arthur, G.D., Lourens, A.F., Novak, O., Strnad, M., and Van Staden, J. 2004. Changes in cytokinin and auxin concentrations in seaweed concentrates when stored at an elevated temperature. Journal of Applied Phycology. 16(1): 
31-39.

Strik, W. A., Novak, M. S. and van Staden, J. 2003. Cytokinins in macroalgae. The Journal of Plant Growth Regulation. 41: 13-24.

Wang, H.M., Li, S. F., and Che H. R. 1993. Polyculture experiments on Gracilaria, Mentapenaeus and Scylla. Journal of Fisheries of China. 17(4) 273-281.

Wellburn, A. R., 1994. The spectral determination of chlorophylls $\mathrm{a}$ and $\mathrm{b}$, as well as total carotenoids, using various solvents with spectrophotometers of different resolution. Journal of plant physiology. 144(3): 307-313.

Yokoya, N. S., 2000. Apical callus formation and plant regeneration controlled by plant growth regulators on axenic culture of the red alga Gracilariopsis tenuifrons (Gracilariales, Rhodophyta). Phycological Research. 48:133-142.

Yokoya, N. S., West, J. A., and Luchi, A. E. 2004. Effects of plant growth regulators on callus formation, growth and regeneration in axenic tissue culture of Gracilaria tenuistipitata and Gracilaria perplexa (Gracilariales, Rhodophyta). Phycological Research. 52: 244-254.

Yong, W. T. L., Ting, S. H., Yong, Y. S., Thien, V. Y., Wong, S. H., Chin, W. L., Rodrigues, K. F., and Anton, A. 2014a. Optimization of culture conditions for the direct regeneration of Kappaphycus alvarezii (Rhodophyta, Solieriaceae). Journal of Applied Phycology. 26:1597-1606.

\section{How to cite this article:}

Anuraj, A., Ajit Arun Waman, Chandra Prakash, S. Dam Roy, M. Viji, Manoj Baidya and Chadha, N.K. 2017. Investigating the Effects of Exogenous Factors on Growth, Photosynthetic Pigments and Bud Induction in Gracilaria corticata var. cylindrica under In vitro Conditions. Int.J.Curr.Microbiol.App.Sci. 6(9): 3235-3246. doi: https://doi.org/10.20546/ijcmas.2017.609.398 